\title{
MINKOWSKI TYPE INEQUALITY FOR CONVEX FUNCTIONS
}

\section{LJILJANKA KVESIĆ AND JOSIP PEČARIĆ}

Abstract. We obtain a Minkowski type inequality for convex functions with weights satisfying the Jensen-Steffensen conditions.

Mathematics subject classification (2010): 26D15.

Keywords and phrases: Minkowski type inequality, convex functions.

\section{REFERENCES}

[1] P. Chunaev, Hölder and Minkowski type inequalities with alternating signs, J. Math. Ineq. (to appear) (arXiv:1310.1286)

[2] P. Chunaev, Lu. Kvesić And J. PeČArić, On Hölder and Minkowski Type Inequalities, Abstr. Appl. Anal., Volume 2014 (2014), Article ID 915635, 5 pages. 